\title{
PENGARUH LEADER MEMBER EXCHANGE (LMX), KEYAKINAN DIRI, DAN BEBAN KERJA TERHADAP KETERIKATAN KERJA KARYAWAN PADA PT AEON CREDIT SERVICE INDONESIA CABANG SURABAYA
}

\author{
Riska Ristia Mashudi ${ }^{1}$, Christina Menuk Srihandayani² \\ Universitas PGRI Adi Buana Surabaya ${ }^{1,2}$ \\ riskaristia3@gmail.com
}

\begin{abstract}
ABSTRAK
Relasi antara pimpinan dan bawahan bisa disebut dengan Leader Member Exchange (LMX) sangatlah penting didalam suatu organisasi oleh karena itu peneliti ingin mengetahui pengaruh Leader Member Exchange (LMX), Keyakinan Diri dan Beban Kerja Terhadap Keterikatan Kerja di PT Aeon Credit Service Indonesia Cabang Surabaya. Populasi dalam riset ini merupakan pegawai di PT ACSI Cabang Surabaya. Pengambilan sampel yang dicoba dengan metode sampling jenuh sejumlah 80 koresponden. Kuisioner adalah metode yang digunakan. Penelitan ini menggunakan uji validitas dan reabilitas dan uji asumsi klasik,uji t dan uji f. Keyakinan diri dan beban kerja dapat mempengaruhi secara positif terhadap keterikatan kerja secara simultan dan parsial.

Kata Kunci : Leader Member Exchange (LMX), Keyakinan Diri, Beban Kerja, Keterikatan Kerja

\section{ABSTRACT}

The relationship between superiors and subordinates can be called as Leader Member Exchange $(L M X)$ is very important in a company or an organization therefore researchers want to know the infuence of Leader Member Exchange (LMX), self efficacy, and workload against work engagment in PT Aeon Credit Service Indonesia branch of surabaya. Sampling is done by saturated sampling method with a numbers of 80 respondents. The questionnare is the method used. This reasources used validity and reliability test, classic assumtion test, and t test also f test. Self efficacy and work load can be positively affect by work engagement in silmutan and partial.
\end{abstract}

Keywords: Leader Member Exchange (LMX), Self Efficacy, Workload, Work Engagement 


\section{PENDAHULUAN}

Perkembangan dunia usaha semakin meningkat dan pekerjaan semakin banyak persaingan. Perusahaan dituntut untuk melakukan suatu perubahan yang positif secara eksternal ataupun internal agar dapat bersaing dengan perusahaan-perusahaan lainnya. Secara internal perusahaan melakukan pengembangan dan penataan pada SDM di dalam perusahaan itu sendiri. Setiap perusahaan dalam mencapai tujuan sangat membutuhkan manusia. Artinya dapat menjalankan aktivitasnya perusahaan membutuhkan tenaga manusia dengan jumlah yang sangat minimal misal dengan teknologi mesin yang sangat canggih dengan penggunaannya tetap membutuhkan manusia, oleh sebab itu manusia ditempatkan Tuhan sebagai makhluk yang paling pintar diantara makhluk hidup lainnya. Sehingga semua aset yang dimiliki SDM yang berkualitas dan mampu menghasilkan tingkat kesejahteraan yang telah diharapkan Khasmir (2016:3). Relasi atasan dan bawahan yang biasa disebut dengan Leader Member Exchange (LMX) yang kurang baik dapat menyebabkan keterikatan kerja karyawan menjadi rendah. Pada dasarnya Leader Member Exchange (LMX) menunjukkan bahwa atasan melihat bawahan yang kuat dalam mengisi peran penting dalam suatu organisasi, sebaliknya peran yang dipandang memiliki peran yang paling dapat membangun hubungan dekat dengan pemimpinnya, hubungan Leader Member Exchange dengan mutu yang tinggi ditandai dengan kepercayaan serta dukungan emosional.

Leader Member Exchange (LMX) berpusat pada hubungan dydac ( 2 arah) antara pemimpin dan masingmasing pengikutnya yang merupakan hubungan pertukaran yang bertujuan dengan menciptakan hubungan yang positif antara pemimpin dengan pengikutnyaa (Wibowo dan Susanto,2013). Leader Member Exchange (LMX) merupakan suatu ikatan yang dibangun oleh pemimpin dan para pengikutnya, dan bersumber padainteraksi yang berlangsungbeberapahari (Amstrong,n2009). Sehingga relasi antara pegawai dan perusahaan tidak bisa dipisahkan. Pegawai tidak hanya sebagai unsur produksi bagi perusahaan tersebut melainkan sebagai investasi perusahaan yang efektif demikian diharapkan setiap pegawai perusahaan akan betah dalam pekerjaannya dan dapat memaknai positif pekerjaan tersebut sehingga akan memaksimalkan pekerjaannya. Kini perusahaan tidak lagi mencari pegawai yang sanggup menginvestasikan diri mereka sendiri agar terlihat penuh disetiap pekerjaan, proaktif, serta memiliki komitmen yang tinggi terhadap standar kualitas kinerjanya dengan itu perusahaan membutuhkan pegawai yang bisa terikat dengan pekerjaannya. Dengan itu adanya relasi yang baik antara pemimpin dan pengikut Leader Member Exchange (LMX) maka semakin tinggi akan keyakinan diri untuk menyelesaikan pekerjaannya. Leader Member Exchange (LMX) sebab itu mutu semakin tinggi akan keyakinan diri untuk menyelesaikan pekerjaannya.

Samuel (2013), menyebutkan keyakinan diri (self efficacy) menempel pada tiap individu, namun sedikit banyaknya yang didukung oleh pihak manajemen. Pegawai yang mempunyai keyakinan diri yang tinggi untuk dapat menyelesaikan tugas secara maksimal dapat mengindikasikan adanya keterikatan kerja yang tinggi. Maka ia akan merasa mampu melaksanakan tugas dengan baik, dapat menyelesaikan tugas dengan tepat waktu, dapat mencapai tujuan yang direncanakan sehingga memiliki sikap dan perilaku yang positif. Selanjutnya aspek yang bisa pengaruhi keterikatan kerja yaitu beban kerja, semakin besar tingkat beban kerja maka semakin kecil keterikatan kerja. Beban kerja ialah sesuatu yang bisa mempengaruhi keterikatan kerja karyawan.

Melalui hal-hal diatas yang telah dijelaskan bahwa penemuan fenomena dalam survey awal ditemukan bahwa PT Aeon Credit Service Indonesia Cabang Surabaya diindikasikan mengalami keterikatan kerja yang rendah. Faktor pertama adalah rendahnya kualitas hubungan secara tidak langsung antara pemimpin dan pengikutnya. Yang berhubungan dalam melakukan pekerjaan, dan juga ditemukan rendahnya keyakinan diri dalam menyelesaikan pekerjaan. Peneliti juga menemukan adanya beban kerja yang mempengaruhi turunnya kualitas kerja. 
Berdasarkan penelitian tersebut maka penulis sangat ingin melakukan penelitian dengan judul "Pengaruh Leader Member Exchange (LMX), Keyakinan Diri, dan Beban Kerja Terhadap Keterikatan Kerja PT Aeon Credit Service Indonesia Cabang Surabaya".

\section{Perumusan Masalah}

Dari maka masalah pokok yang terjadi, fokus pembahasan dalam riset ini yaitu:

1. Apakah Leader Member Exchange (LMX) berpengaruh terhadap keterikatan kerja karyawan pada PT Aeon Credit Service Indonesia Cabang Surabaya?

2. Apakah keyakinan diri berpengaruh terhadap keterikatan kerja karyawan pada PT Aeon Credit Service Indonesia Cabang Surabaya?

3. Apakah Beban Kerja berpengaruh terhadap keterikatan kerja karyawan pada PT Aeon Credit Service Indonesia Cabang Surabaya?

4. Apakah Leader Member Exchange (LMX), keyakinan diri, dan beban kerja berpengaruh terhadap keterikatan kerja karyawan pada PT Aeon Credit Service Indonesia Cabang Surabaya?

\section{TINJAUAN PUSTAKA}

\section{Leader Member Exchange (LMX)}

Graen dan Uhl-Bien dalam (Wibowo dan Susanto, 2013) Mengartikan Leader Member Exchange (LMX) bahwa LMX suatu relasi antara pimpinan dan bawahan yang bertujuan untuk menyatukan hubungan yang baik dan meningkatkan kesuksesan dalam suatu perusahaan.

\section{Keyakinan Diri}

Menurut Bandura dalam Putri (2015) ialah suatu keyakinan yang dimiliki seseorang untuk bias melakukan pekerjaan dengan hasil yang maksimal sehingga karyawan bisa mengerjakannya.

\section{Beban Kerja}

Menurut Koesmowidjojo (2017:22) beban kerja ialah tuntutan pekerjaan pada karyawan dengan jam yang tinggi sehingga para karyawan dituntut memberikan kuantitas dan kualitas dalam bekerja.

\section{Keterikatan Kerja}

Robbins et al dalam Aliyah (2017) yang mengartikan keterikatan karyawan ialah suatu sikap positif individu karyawan yang memiliki kepemahaman dan kepedulian terhadap lingkungan perusahaan sehingga karyawan dapat terikat dengan pekerjaan yang diampunya.

\section{Kerangka Konseptual}

Dalam penelitian ini akan diteliti tentang pengaruh Leader Member Exchange $\left(X_{1}\right)$, Keyakinan Diri $\left(X_{2}\right)$, dan Beban Kerja $\left(\mathrm{X}_{3}\right)$ Terhadap Keterikatan Kerja (Y) di PT Aeon Credit Service Indonesia Cabang Surabaya. Sehingga kerangka konseptual seperti di bawah ini: 


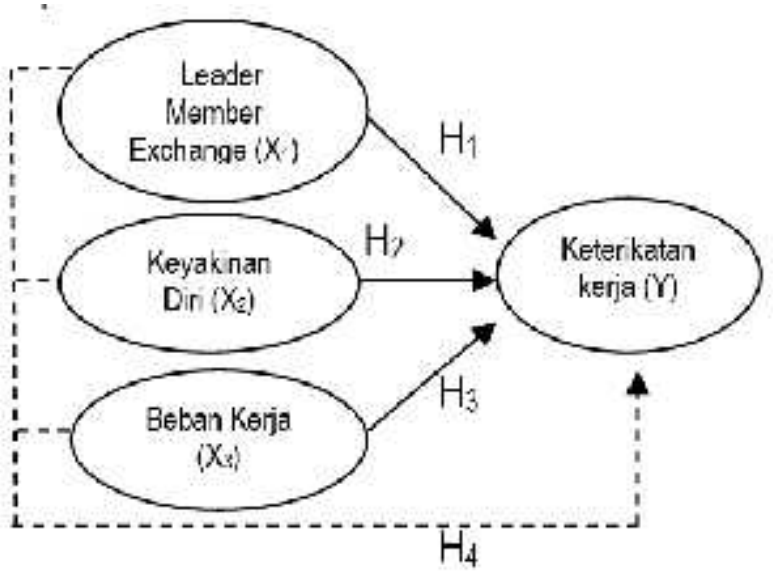

Gambar 1. Kerangka Konseptual

\section{Hipotesis}

Adapun Hipotesis dalam penelitan ini, yaitu :

$\mathrm{H}_{1}$ : Leader Member Exchange(LMX) berpengaruh positif dan signifikan terhadap keterikatan kerja pada karyawan PT Aeon Credit Service Indonesia.

$\mathrm{H}_{2}$ : Keyakinan Diri yang bisa mempengaruhi positif terhadap Keterikatan Kerja karyawan pada PT Aeon Credit Service Indonesia.

$\mathrm{H}_{3:}$ Beban Kerja berpengaruh positif terhadap Keterikatan Kerja pada karyawan PT Aeon Credit Service Indonesia.

$\mathrm{H}_{4}$ : Leader Member Exchange(LMX), Keyakinan Diri, dan Beban Kerja. berpengaruhh positif terhadap Keterikatan Kerja pada Karyawan

\section{METODE PENELITIAN}

Populasi dan Sampel

Dalam riset ini mengunakan pengambilan sampel dilakukan dengan teknik sampling jenuh dengan sejumlah 80 respoden. Kuisioner adalah metode yang digunakan. Penelitan ini menggunakan uji validitass dan reabilitass,serta asumsi klasik,uji t dan uji f. Keyakinan diri dan beban kerja dapat mempengaruhi secara positif terhadap keterikatan kerja baik simultan dan parsial. 
HASIL PENELITIAN DAN PEMBAHASAN

Uji Instrumen Penelitian

Uji validitas

Tabel1

Hasil Uji Validitas

\begin{tabular}{|c|c|c|c|}
\hline $\begin{array}{c}\text { Item } \\
\text { Pertanyaan }\end{array}$ & $\begin{array}{l}\text { Corrected } \\
\text { hem-Total } \\
\text { Corralation }\end{array}$ & $\begin{array}{l}\text { Nilai } \\
\text { Kritis }\end{array}$ & Keterangan \\
\hline \multicolumn{4}{|c|}{ Varlabel Leader Member Exchange } \\
\hline$x: 1$ & 0.576 & 0.3 & Valin. \\
\hline$\times 2$ & 0.702 & 0,3 & Valid \\
\hline$\times 3$ & 0.731 & 03 & Valid \\
\hline$x .4$ & 0.737 & 03 & Valid \\
\hline$\times 5$ & 0.716 & 0.3 & Valis \\
\hline$x \cdot 6$ & 1) $/ 31$ & 0.3 & Vidilid \\
\hline$x .7$ & 0.8 & 03 & Vallo \\
\hline$\times 8$ & 0.649 & 0.3 & Valid \\
\hline$\times 9$ & 0.731 & 03 & Valio \\
\hline$x_{1} 10$ & (1) & 0,3 & Valid \\
\hline$x .11$ & 0.722 & 03 & Valid \\
\hline$x_{4} 12$ & 0.673 & 03 & Valid \\
\hline$x_{1} 13$ & 0.73 & 03 & Valid \\
\hline
\end{tabular}

Variabel Keyakinan Diri

\begin{tabular}{|c|c|c|c|}
\hline$x_{0} \cdot 1$ & 01795 & 03 & $\mathrm{~V}$ ali \\
\hline$\times 2$ & $0 / 4 \mathrm{~S}$ & 13 & Valid \\
\hline$X_{6} .3$ & 0783 & 03 & Vetlid \\
\hline$x 4$ & $0 / 30$ & 13 & Valis \\
\hline$x, 5$ & 0178 & 03 & Valid \\
\hline$\times 6$ & $0 / 16^{\circ}$ & 13 & Valit \\
\hline$X_{2.7}$ & 0743 & 8,3 & Welid \\
\hline$x_{2} 8$ & 074? & 1,3 & Welit \\
\hline$\times 9$ & 0791 & 03 & Valid \\
\hline$x_{2} \geq 0$ & 0794 & 1,3 & tislit \\
\hline $\mathrm{x}: 11$ & 0737 & 83 & $\mathrm{~V} / \mathrm{arJ}$ \\
\hline$x_{2} \geq 2$ & 0765 & 183 & Visilit \\
\hline$x .13$ & 0798 & 83 & Valid \\
\hline
\end{tabular}




\begin{tabular}{|c|c|c|c|}
\hline \multicolumn{4}{|c|}{ Variabs Beban Keria } \\
\hline$x_{3.1}$ & 0.872 & 0,3 & Valio \\
\hline$x_{3.2}$ & 0.894 & 0,3 & Valio \\
\hline$X_{3} 3$ & 0.782 & 0,3 & Valid \\
\hline$X_{3}, 4$ & 0.893 & 0,3 & Valid \\
\hline$\times 3.5$ & 0.849 & 0,3 & Valid \\
\hline$x_{3} 6$ & 0.884 & 0,3 & Valid \\
\hline$X_{3.7}$ & 0.816 & 0,3 & Valid \\
\hline$X_{3.8}$ & 0.9 & 0,3 & Valio \\
\hline$x_{3} .9$ & 0.8 & 0.3 & Valio \\
\hline$x_{3}, 10$ & 0.818 & 0,3 & Valid \\
\hline$x_{3.11}$ & 0.837 & 0,3 & Valio \\
\hline$x_{3}, 12$ & 0.789 & 0,3 & Valid \\
\hline \multicolumn{4}{|c|}{ Variabel Keterikatan Kerja } \\
\hline Y.1 & 0779 & 0,3 & Valid \\
\hline Y.2 & 0346 & 0,3 & Valid \\
\hline$Y_{3}$ & 0304 & 0,3 & Valid \\
\hline$Y .4$ & 0721 & 0,3 & Valid \\
\hline$Y .5$ & 0779 & 0,3 & Valid \\
\hline$Y .6$ & 0.343 & 0,3 & Valid \\
\hline Y.7 & 0774 & 0,3 & Valid \\
\hline Y.8 & 0744 & 0,3 & Valid \\
\hline Y.g & 0.307 & 0,3 & Valid \\
\hline$Y .10$ & 0764 & 0,3 & Valid \\
\hline Y.11 & 0736 & 0,3 & Valid \\
\hline Y.12 & 0733 & 0,3 & Valid \\
\hline
\end{tabular}


Dari tabel 1 semua instrumen menunjukkan bahwa semua item pada pernyataan di atas dinyatakan valid, sebab didapatkan dengan nilai Corrected Item-Total correlation $>0,3$. Jadi, semua indikator dinyatakan valid sehingga bisa jadi tolok ukur suatu Variabel.

\section{Uji Reliabilitas}

\begin{tabular}{|c|c|c|c|}
\hline Variabel & $\begin{array}{l}\text { Cronbach's } \\
\text { Alpha }\end{array}$ & $\begin{array}{l}\text { Nilai } \\
\text { Kritis }\end{array}$ & Keterangan \\
\hline $\begin{array}{l}\text { Leasder Wember } \\
\text { Exchange }\left(X_{1}\right)\end{array}$ & 0940 & 0,70 & Reiacel \\
\hline $\begin{array}{l}\text { Keyakinan Diri } \\
\left(X_{2}\right)\end{array}$ & 0954 & 0,70 & Reiabel \\
\hline Eeban Kerja $\left[X_{3}\right]$ & 0971 & 0,70 & Reiacel \\
\hline $\begin{array}{l}\text { Keterikatan Kerja } \\
\text { (Y) }\end{array}$ & 0954 & 0,70 & Reiacel \\
\hline
\end{tabular}

Dari tabel 2 semua variabel menunjukkan nilai koefisien reliabitas Cronbach alpha lebih dari 0,70. Sehingga instrumen reliabel.

\section{Uji Asumsi Klasik}

Tabel 3 Hasil Uji Asumsi Klasik

\begin{tabular}{lcc}
\hline Uji Asumsi & Hasil & Kriteria \\
\hline Normalitas & & \\
\hline Test stabistic & 0,057 & $>0,05$ \\
Asyamp Sig & 0,853 & $>0,05$ \\
\hline Multikolenieritas & & \\
\hline LMX & 566 & 1500 \\
Keyakinan Dir & .503 & 1660 \\
Beban Kerja & .760 & 1.315 \\
\hline Autokorelasi & & \\
\hline Durbin-watscn 1.800) & & \\
\hline
\end{tabular}




\section{Heteroskedastisitas}

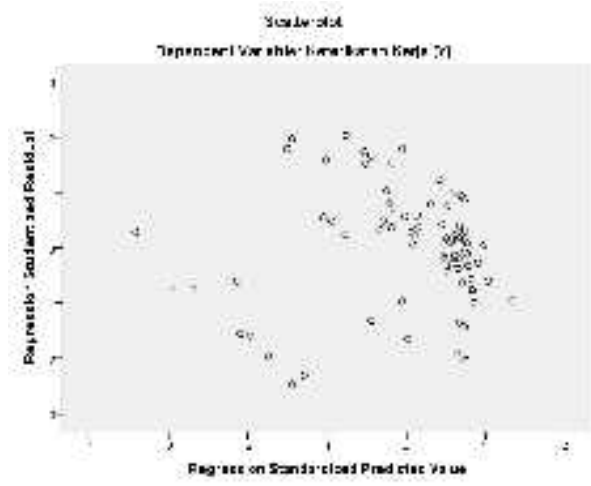

Gambar 2 Scatterplot

Gambar scatterplot menunjukkan bahwa residu tidak membentuk pola tertentu dan diakhir angka nol. Maka bisa disebut uji heteroskedastisitas yang dilakukan dengan uji scatterplot menyatakan bebas heteroskedastisitas.

Uji Normalitas didapat dengan nilai sig $>0,05$, maka semua data berdistribusi normal. Kemudian uji $t$ untuk ketiga variabel independen residual diperoleh nilai sig $>0,05$, berarti pada model regresi tidak terjadi heteroskedastisitas. Uji multikolinieritas, diketahui nilai tolerance masing-masing variabel $>0,10$ dan nilai VIF< 10, sehingga tidak terjadimultikolinieritas antar variabel independen. Sedangkan hasil uji autokorelasi mendapatkan hasil Durbin-Watson didapatkan sebesar 1,880.sedangkannilai DL pada tabel DW sebesar 1,560 dan nilai DU sebesar 1,715. Ada ataupun tidak autokorelasi dapat dilihat dari rumus DL < DW < 4-DU sehingga $1,560<1,880<2,285$. maka dapat di simpulkan bahwa model regresi tersebut tidak adanya masalah atau bebas uji autokorelasi.

\section{Analisis Regresi Linier Berganda}

Tabel 4

Analisis Regresi Linier Berganda

\begin{tabular}{|c|c|c|c|}
\hline \multirow{2}{*}{\multicolumn{2}{|c|}{ Model }} & \multicolumn{2}{|c|}{$\begin{array}{l}\text { Unsiandardized' } \\
\text { Coefficientis }\end{array}$} \\
\hline & & $\bar{B}$ & Std. Error \\
\hline \multirow{4}{*}{1} & (Constant) & 4.687 & 4.888 \\
\hline & $\begin{array}{l}\text { Leader Member } \\
\text { Exchange (X1) }\end{array}$ & 0.401 & 0.099 \\
\hline & Keyakinan Diri (X2) & 0.205 & 0.094 \\
\hline & Beban Kerjs (X3) & 0.273 & 0.071 \\
\hline
\end{tabular}

Model diatas dapat dijelaskan sebagai berikut :

$$
Y=4,687+0,401 X_{1}+0,205 X_{2}+0,273 X_{3}
$$

Dapat dijelaskan dari persamaan diatas sebegai berikut :

a. Nilai konstanta (a) sebesar 4,687 yang menunjukkan apabila variable bebas sama dengan nol maka variable terikat bernilai sebesar 4,687satuan. 
b. Koefisien Variabel leader member exchange $\left(X_{1}\right)$ didapatkan nilai sebesar 0,401dan memiliki nilai koefisien positif $(+)$, karna itu terdapat pengaruh yang sejalan antara variabel leader member exchange $\left(X_{1}\right)$ dengan variable keterikatan kerja( $\mathrm{Y})$, yang artinya setiap peningkatan nilai variable leader member exchange $\left(\mathrm{X}_{1}\right)$, dari itu maka meningkatkan nilai Variabel keterikatan kerja $(Y)$ sebesar 0,401.

c. Koefisien Variabel keyakinan diri $\left(X_{2}\right)$ didapatkan nilai sebesar 0,205 dan memiliki nilai koefisien positif $(+)$, hal tersebut menunjukkan bahwa terdapat pengaruh yang sejalan antara variable keyakinan diri $\left(\mathrm{X}_{2}\right)$ dengan variable keterikatan kerja $(\mathrm{Y})$, yang artinya setiap peningkatan nilai variable keyakinan diri $\left(\mathrm{X}_{2}\right)$, maka akan menambah nilai variabel keterikatan kerja $(Y)$ sebesar 0,205.

d. Koefisien Variabel beban kerja $\left(X_{3}\right)$ didapatkan nilai sebesar 0,273 dan memiliki nilai koefisien positif $(+)$, hal tersebut dapat menunjukkan pengaruh variabel yang sejalan antara variable beban kerja $\left(X_{3}\right)$ dengan variable keterikatan kerja( $\mathrm{Y})$, yang artinya setiap peningkatan nilai variable beban kerja $\left(\mathrm{X}_{3}\right)$, maka akan menambah nilai Variabel keterikatan kerja $(Y)$ sebesar 0,273.

\section{Pengujian Hipotesis \\ Uji T (parsial)}

Tabel 5

Hasil Pengujian HipotesisUji-t

\begin{tabular}{lcc}
\hline Model & $T$ & Sig. \\
\hline (Constant) & 0.959 & 0.341 \\
LeaderMember & 4.050 & 0.000 \\
1 Exchange $\left(X_{1}\right)$ & & \\
Keyakinan Diri $\left(X_{2}\right)$ & 2.183 & 0.032 \\
Beban Kerja $\left(X_{3}\right)$ & 3.846 & 0.000 \\
\hline
\end{tabular}

Dapat dijelaskan dari tabel diatas sebagai berikut:

1) Hasil tersebut bisa dikatakan bahwa hipotesis diterima yang artinya Leader Member Exchange (LMX) yang berpengaruh positif dan signifikan terhadap keterikatan kerja karyawan pada PT Aeon Credit Service Indonesia Cabang Surabaya.

2) Hasil menunjukkan bahwa nilai thitung pada variable keyakinan diri sebesar 2,183 dengan nilai sig sebesar $0,032(0,032<0,05)$. Dari hasil tersebut bisa dinyatakan bahwa hipotesis diterima yang artinya Keyakinan Diri berpengaruh positif dan signifikan terhadap keterikatan kerja karyawan pada PT Aeon Credit Service Indonesia Cabang Surabaya.

3) Hasil pengujian uji t pada tabel 4.5 diatas menyebutkan bahwa nilai thitung pada variable Beban Kerja sebesar 3,846 dengan nilai sig sebesar 0,000 $(0,000<0,05)$. maka hasil dikatakan bahwa hipotesis diterima, yang artinya Beban Kerja berpengaruh positif terhadap Keterikatan Kerja karyawan pada PT Aeon Credit Service Indonesia Cabang Surabaya. 


\section{Uji F (simultan)}

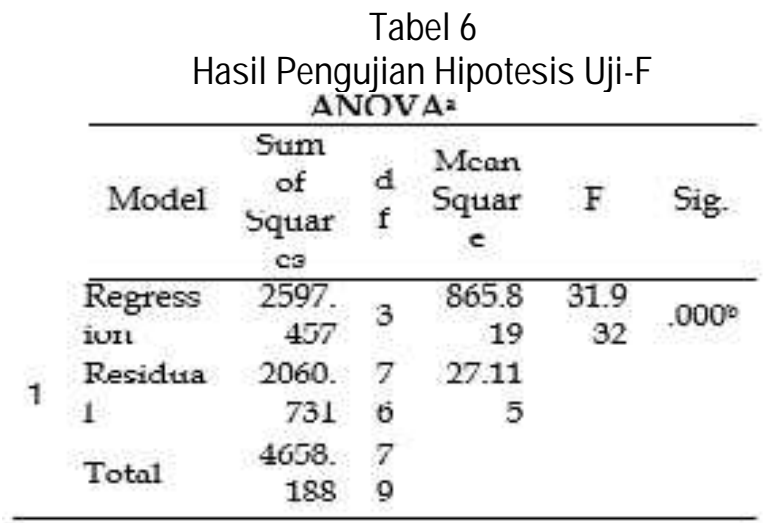

Hasil pengujian hipotesis 4 menggunakan Uji-F. Diperoleh nilai sigsebesar< 0,05. maka dari hasil tersebut dinyatakan Hipotesis diterima. Yang artinya Leader Member Exchange (LMX), Keyakinan Diri, dan Beban Kerjasecara simultan berpengaruh positif terhadap Keterikatan Kerja pada Karyawan PT Aeon Credit Service Indonesia. Hasil penelitian ini juga sejalan dengan penelitian yang pernah dilakukan oleh Hikmatul Aliyah (2017) bahwa beban kerja berpengaruh terhadap keterikatan kerja. Hasil dari riset menyatakan Lingkungan kerja, Status kerja dan Beban Kerja berpengaruh secara simultan terhadap Keterikatan Kerja.

\section{SIMPULAN}

1. Leader Member Exchange (LMX) berpengaruh positif dan signifikan terhadap keterikatan kerja (Work Engagement) pada karyawan PT Aeon Credit Service Indonesia. Berdasarkan hasil pengujian uji-t. Dari hasil pengujian tersebut menunjukkan bahwa hasil yang diterima dan terbukti kebenarannya.

2. Keyakinan diri berpengaruh positif dan signifikan terhadap keterikatan kerja (Work Engagement) pada karyawan PT Aeon Credit Service Indonesia. Berdasarkan hasil pengujian uji-t. Dari hasil pengujian tersebut menunjukkan bahwa hasil yang diterima dan terbukti kebenarannya.

3. Beban kerja berpengaruh positif dan signifikan terhadap keterikatan kerja (Work Engagement) pada karyawan PT Aeon Credit Service Indonesia. Berdasarkan bahwa hasil uji-t. Dari hasil pengujian tersebut menunjukkan bahwa hasil yang diterima dan terbukti kebenarannya.

4. Leader Member Exchange (LMX), keyakinan diri dan beban kerja secara simultan berpengaruh positif dan signifikan terhadap keterikatan kerja (Work Engagement) pada karyawan PT Aeon Credit Service Indonesia. Berdasarkan dari hasil uji-t. Dari hasil pengujian tersebut menunjukkan bahwa hasil yang diterima dan terbukti kebenarannya

\section{IMPLIKASI}

Dalam suatu perusahaan sangatlah penting untuk menjalin suatu relasi antara pemimpin dan pengikutnya, guna menambah keyakinan diri saat bekerja dan dapat meningkatkan kualitas yang baik saat bekerja.

\section{KETERBATASAN PENELITIAN}

Berdasarkan riset ini peneliti menggunakan tiga variabel independen yaitu Leader Member Exchange, Keyakinan Diri dan Beban Kerja. Dengan itu penelitian diharapkan dapat menambahkan variabel lain yang lebih menginofasi pengaruh keterikatan kerja yang belum digunakan. Saat menyebar kuesioner konsumen masih ada 
yang menjawab pernyataan tidak sesuai dengan kondisi yang ada. Terbatasnya waktu dan tenaga serta biaya membuat sedikit kendala pada saat pengambilan data.

\section{DAFTAR PUSTAKA}

Allen,dan Mohammad Iqbal, 2018, Pengaruh Leader Member Exchange (LMX) Dan Motivasi Kerja Terhadap Loyalitas Karyawan, Jurnal Administrasi Bisnis (JAB), Volume 58, No. 2, Hal 179-187.

Amstrong, M.2009,Armstrong'shandbookof managementand leadership aguide to managing for result (2ndEd,). London: Kogan Page.

Khasmir, 2016, Manajemen Sumber Daya Manusia (Teori dan Praktek). Jakarta: PT Raja Grafindo Persada. Koesmowidjojo, S. R. M, 2017, Analisis Beban Kerja (bahasa Indonesia, Jakarta : Raih Asa Sukses.

Rindang, 2014, Pengujian Power Distance Sebagai Moderator Hubungan Keyakinan diri, Leader Member Exchange dengan Keterikatan Kerja, jurnal psikologi industri, hal 1-22.

Samuel, N.K. 2013, Kepemimpinan Transformasional, Self Efficacy, Self Esteem dan pengaruhnya terhadap kepuasan kerja Karyawan PT. Tropica Cocoprima Manado. Jurnal EMBA 141, 1 (4): 141-150.

Wibowo, Jeffry \& Eddy M. Susanto,2013, Pengaruh Leader Member Exchange (LMX), Motivasi Kerja dan Kepuasan Kerja Terhadap Loyalitas Karyawan. Vol. 1, No 3. Hal 1-8.

Nursito, Suwarno, 2013, Analisis Pengaruh Interaksi Pengetahuan Kewirausahaan dan Efikasi Diri Terhadap Intensi Kewirausahaan, Jurnal Kiat BISNIS, volume 5, No. 3, Hal 201-211.

Nusantara, Billy Kharisma, 2015, Pengaruh Leader Member Exchangedan Budaya Organisasi Terhadap Loyalitas Karyawan. Universitas Negri Yogyakarta.

Putri, Aditya Nanda Priyatama, dan Nugraha Arif Karyanta,2015, Hubungan Antara Efikasi Diri dan Optimisme dengan Keterikatan pada Karyawan PT Bank Tabungan Negara (Persero) Cabang Solo. 